НАУКОВИЙ ВІСНИК

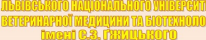

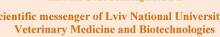
ming (1) 11) HIMIMI

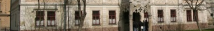

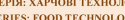
Том 23 № 95 2021
Науковий вісник Дьвівського національного університету ветеринарної медицини та біотехнологій імені С.3. Гжицького. Серія: Харчові технології

Scientific Messenger of Lviv National University of Veterinary Medicine and Biotechnologies.

Series: Food Technologies

UDC 637.146.34

\title{
The use of cryopowder from seafood in the technology of thermostatic yogurt for therapeutic and prophylactic purposes
}

\author{
Y. R. Hachak, V. A. Nahovska, B. V. Gutyj \\ Stepan Gzhytskyi National University of Veterinary Medicine and Biotechnologies Lviv, Ukraine
}

\section{Article info}

Received 02.02.2021

Received in revised form 03.03 .202

Accepted 04.03.2021

Stepan Gzhytskyi National University of Veterinary Medicine and Biotechnologies Lviv, Pekarska Str., 50, Lviv, 79010, Ukraine. Tel.: +38-097-331-99-23 E-mail: hachakyuriy@gmail.com
Hachak, Y. R., Nahovska, V. A., Gutyj, B. V. (2021). The use of cryopowder from seafood in the technology of thermostatic yogurt for therapeutic and prophylactic purposes. Scientific Messenger of Lviv National University of Veterinary Medicine and Biotechnologies. Series: Food Technologies, 23(95), 83-90. doi: 10.32718/nvlvet-f9514

The basis of the technology of functional foods, as is known, is the presence of high content of nutrients, the ability to influence certain parts of the potential consumer. Fermented milk products in this regard are natural representatives of this group. The use of sour milk drinks with phytonutrients of different physical state will contribute not only to additional profits due to the sale of new biologically valuable and very important for public health products, but also to solve such an important problem of all food companies as complex processing of raw materials. related environmental issues. Taking into account the relevance of the topic, research was planned to study the possibility of using a new domestic cryoadditive - cryopowder "Morska Kapusta" in the technology of such a popular sour milk drink as yogurt. Scientific research was conducted in the scientific laboratory of the Department of Milk Technology and Dairy Products of Stepan Gzhytskyi National University of Veterinary Medicine and Biotechnologies Lviv and in production. Formulations of thermostatic yoghurts (1.5\%) with cryopowder of domestic production "Morska Kapusta" were developed and proposed for industrial production. The technological scheme of production of thermostatic yoghurts (mchzh $1.5 \%$ ) with cryopowder of domestic production "Morska Kapusta" is offered. The main organoleptic and technological characteristics of thermostatic yogurts (1.5\%) with cryopowder of domestic production "Morska Kapusta" were studied. Experimental samples of thermostatic yogurts (1.5\% weight) with cryopowder of domestic production "Morska Kapusta" had high levels of all regulatory vitamins. The proposed types of thermostatic yogurts (1.5\%) with cryopowder "Morska Kapusta" are characterized by an increase in the amount of sulfur-containing amino acids (methionine + cystine) and tryptophan, and the lack of limiting amino acids in the combined sample of yogurt indicates an increase in biological value. Prototypes of thermostatic yogurts $(1.5 \%)$ with cryopowder of domestic production "Morska Kapusta" retained the technological characteristics and regulatory safety indicators during the standard storage time.

Key words: yogurt, cryopowder "Morska Kapusta", herbal supplements, technology.

\section{Застосування кріопорошку із морепродуктів в технології термостатного йогурту лікувально-профілактичного призначення}

\author{
Ю. Р. Гачак, В. О. Наговська, Б. В. Гутий
}

Львівський національний університет ветеринарної медицини та біотехнологій імені С. 3. Гжицького, м. Львів, Україна

Основою технологї функціональних харчових продуктів, як відомо, є наявність у них підвищеного вмісту поживних інгредієнтів, здатність впливати на ті чи інші ланки потенційного споживача. Кисломолочні продукти в цьому плані є природними представниками даної групи. Використання кисломолочних напоїв із фітодобавками різного агрегатного стану буде сприяти не тільки одержанню додаткових прибутків внаслідок реалізачї̈ нових біологічно-повночінних і дуже важливих для здоров'я населення продуктів, а й виріменню такої важливої проблеми всіх харчових підприємств, як комплексна переробка сировини, і безпосередньо зв'язаної з нею проблеми охорони навколишнього середовища. Врахувавши актуальність тематики, були заплановані дослідження 
щчодо вивчення можливості застосування нової вітчизняної кріодобавки - кріопорошку “Морська капуста” в технологї такого популярного кисломолочного напою як йогурт. Наукові дослідження проводились в умовах наукової лабораторії кафедри технології молока і молочних продуктів Львівського національного університету ветеринарної медицин та біотехнології ім. С. 3 . Гжицького i на виробництві. Розроблені та запропоновані для промислового виробництва рецептури термостатних йогуртів (мчж 1,5 \%) із кріопорошком вітчизняного виробництва "Морська капуста". Запропонована технологічна схема виробництва термостатних йогуртів (мчж 1,5\%) із кріопорочком вітчизняного виробництва “Морська капуста”. Вивчено основні органолептичні та технологічні характеристики термостатних йогуртів (мчж 1,5%) із кріопорошком вітчизняного виробництва “Морська капуста”. Дослідні зразки термостатних йогуртів (мчж 1,5\%) із кріопорошком вітчизняного виробництва “Морська капуста” мали підвищені показники вмісту усіх нормативно передбачених вітамінів. Пропоновані види термостатних йогуртів (мчж 1,5 \%) із кріопорошком “Морська капуста" характеризуються зростанням скору суми сірковмісних амінокислот (метіонін + цистин) і триптофану, а відсутність лімітуючих амінокислот в комбінованому зразку йогурту свідчить про підвищення біологічної иінності продукту. Дослідні зразки термостатних йогуртів (мчж 1,5\%) із кріопорошком вітчизняного виробництва “Морська капуста” зберігали технологічні характеристики та нормативні показники безпеки протягом нормативного часу зберігання.

Ключові слова: йогурт, кріопорошок “Морська капуста”, фітодобавки, технологія.

\section{Вступ}

Проблема забезпечення населення раціональним та збалансованим харчуванням $\epsilon$ на теперішній час дуже актуальною. Зважаючи на сучасні екологічні умови, раціон харчування людини повинен містити в собі природні біологічно активні речовини, які здатні підвищувати резистентність організму. Технології харчових функціональних продуктів насамперед спрямовані на збереження корисних речовин їжі, оскільки вона є природним функціональним продуктом (Hachak et al., 2015; Smith et al., 2016; Gutyj et al., 2017; Bilyk et al., 2017; Hachak et al., 2018).

Останніми роками серед значної кількості харчових продуктів виробництво молочних продуктів також видозмінюється, а відповідно з цим і потреби та уподобання споживачів стосовно асортименту молочних продуктів (Pinheiro et al., 2005).

У даний час перевага за тими продуктами, які мають здатність очищати організм від радіонуклідів, важких металів, шлаків, забезпечують його нормальне функціонування та посилюють резистентність до несприятливих факторів навколишнього середовища, тому такі речовини, які мають абсорбуючі, адсорбційні властивості, швидко виводяться 3 організму (Berhilevych et al., 2010).

Основою технології функціональних харчових продуктів, як відомо, є наявність у них підвищеного вмісту поживних інгредієнтів, здатність впливати на ті чи інші ланки потенційного споживача. Кисломолочні продукти в цьому плані є природними представниками даної групи (Steshenko \& Haiho, 2016).

Постійне споживання кисломолочних продуктів зміцнює нервову систему, тому що в них нагромаджуються необхідні для людини вітаміни, які синтезуються молочнокислими бактеріями. Після вживання цих продуктів молочна кислота, яку утворюють бактерії під час молочнокислого бродіння, пригнічує в кишках гнильну мікрофлору і тим сприяє довголіттю (Vlasenko, 2013; Ramazashvili \& Kruchen, 2016).

Не є винятком у цьому використання “молочної основи" кисломолочних напоїв, в тому числі і йогурту. Йогурт є цікавим та оригінальним рішенням у розширенні сучасного асортименту молочних продуктів лікувально- профілактичного спрямування (Reis et al., 2011).

Використання кисломолочних напоїв із фітодобавками різного агрегатного стану буде сприяти не тіль- ки одержанню додаткових прибутків внаслідок реалізації нових біологічно-повноцінних і дуже важливих для здоров'я населення продуктів, а й вирішенню такої важливої проблеми всіх харчових підприємств, як комплексна переробка сировини, і безпосередньо зв'язаної 3 нею проблеми охорони навколишнього середовища (Yatsenko et al., 2016).

Вченими розроблено численні молочно-білкові композиції сиркових паст, напоїв, збагачених фітодобавками, вітамінами та мікроелементами (Yatsenko et al., 2016; Hoshko \& Tsisaryk, 2016; Steshenko \& Haiho, 2016; Ramazashvili \& Kruchen, 2016).

Попит на функціональні продукти у світі зростає, що спонукає до розробки нових та збільшення об'єму виробництва уже вживаних продуктів. Перспективним є виробництво підприємствами харчової промисловості продуктів лікувально-профілактичного призначення, в тому числі молочних із застосуванням фітодобавок, зокрема у вигляді різноманітних кріопорошків (Hoshko \& Tsisaryk, 2016).

У зв'язку із цим використання кріопорошків як додаткових рецептурних складників в технології нетрадиційних молочних продуктів є цікавим, виправданим, корисним для науки, 3 подальшим якнайшвидшим впровадженням у виробничий цикл молокопереробних підприємств України, що зацікавлені у виробництві та розширенні асортименту кисломолочних напоїв (Gutyj et al., 2017).

Цінний хімічний склад, висока поживна та біологічна цінність, ефективна лікувально-профілактична дія кріопорошків $є$ вагомими факторами використання їх не лише в медицині, а й у харчовій промисловості. Загальновідомі лікувальні властивості кріопорошків обумовлені наявністю в них величезної кількості біологічно активних речовин. Дані кріодобавки здійснюватимуть на наш організм суттєвий вплив. Актуальність використання кріопорошків, до яких належать і кріопорошки із рослин, значно зросла в останні десятиліття. Останніми роками кріопорошками профілактують та лікують численні захворювання і органів дихання, і органів харчування, і серцево-судинної системи, і органів сечовипускання та багатьох інших (Hachak et al., 2018).

Врахувавши актуальність тематики досліджень, були заплановані дослідження щодо вивчення можливості застосування нової вітчизняної кріодобавки кріопорошку "Морська капуста" в технології такого популярного кисломолочного напою як “йогурт”. 


\section{Матеріал і методи досліджень}

Наукові дослідження проводилися в умовах наукової лабораторії кафедри технології молока і молочних продуктів Львівського національного університету ветеринарної медицини та біотехнології ім. С. 3. Гжицького та на виробництві. Проведено декілька серій експериментів, спрямованих на розробку рецептур йогуртів із кріопорошком "Морська капуста" та дослідження органолептичних і технологічних показників дослідних зразків фруктових йогуртів. Як наповнювач та смаковий і природний барвник пропонований кріопорошок "Морська капуста". Як молочну основу використано нормалізовану суміш із мчж $1,5 \%$. Виробництво пропонованого йогурту здійснюватиметься термостатним способом.

Кріопорошок "Морська капуста" - кріодобавка із морської капусти (рис. 1). Морська капуста, або ламінарія - зелена або бура водорость, що росте в північних морях та Японському морі.

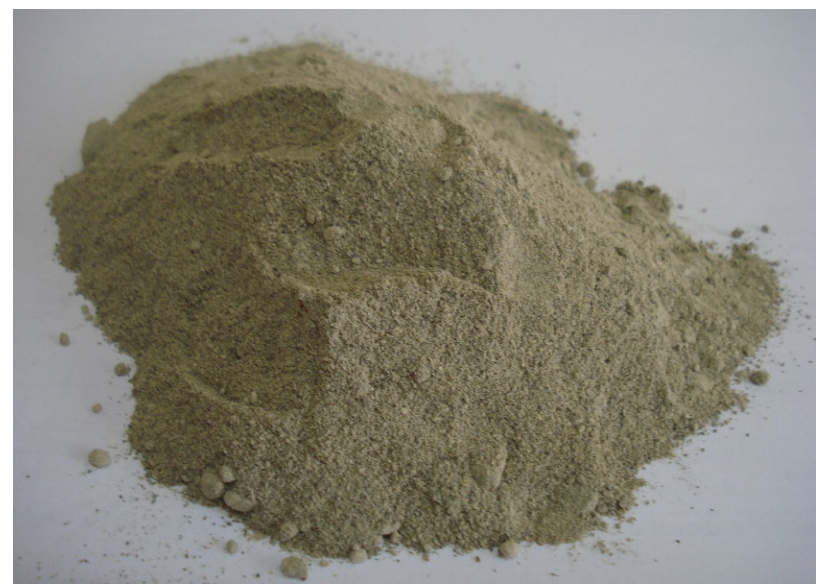

Рис. 1. Кріопорошок "Морська капуста"

Ламінарія росте великими пластинами або стрічками. Завдовжки кожна пластина ламінарії може досягати 13 метрів. Лікувальні властивості морської капусти були відомі людям давно.

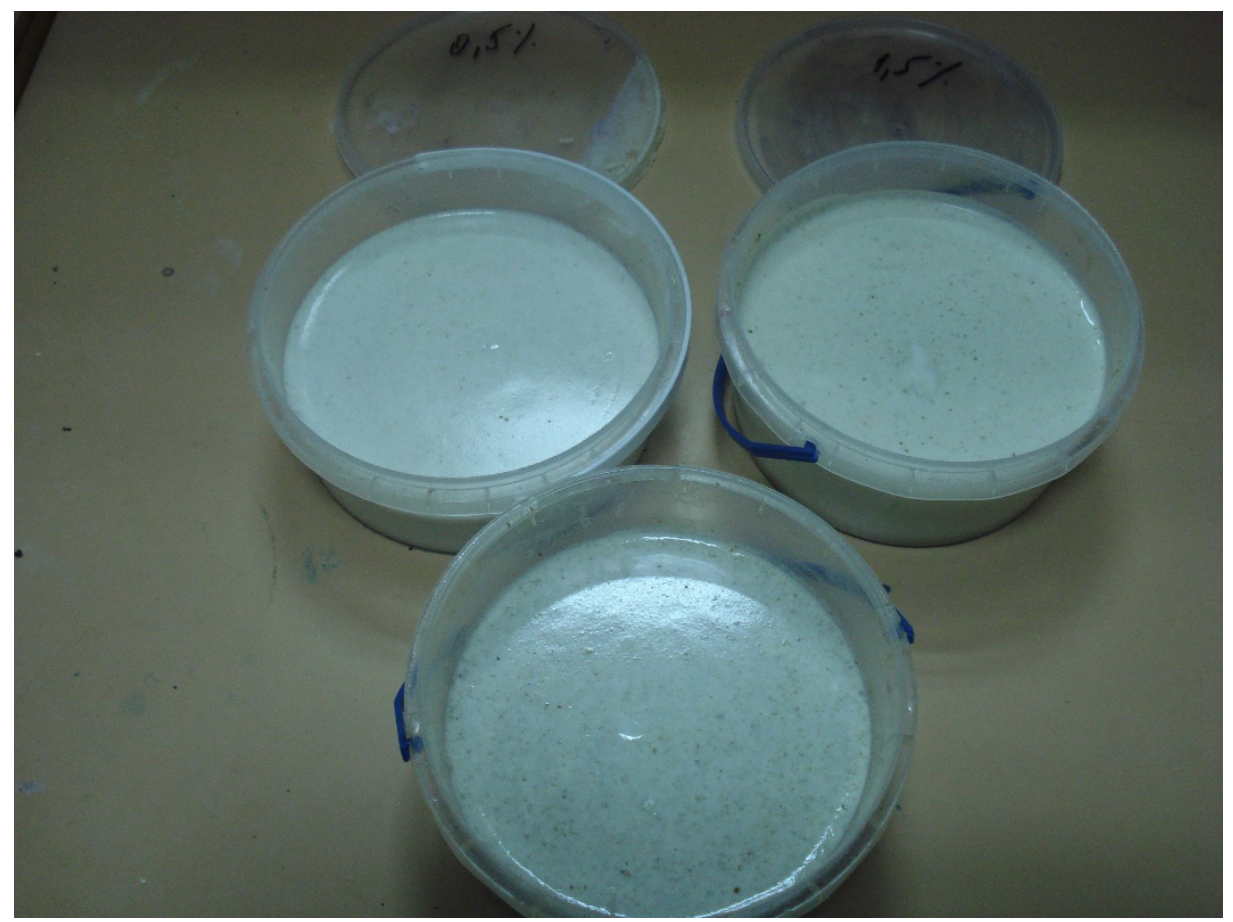

Рис. 2. Дослідні зразки

Дози пропонованої фітодобавки розроблялись на основі рекомендованих добових норм споживання для різних вікових груп, лікувально-профілактичних доз біодобавки.

Як заквашувальний фактор використано закваску прямого внесення “in vivo". Дана закваска містить корисні живі бактерії, які входять до складу нормальної мікрофлори людини.

Бактеріальний склад пропонованої та використаної закваски:

Streptococcus thermophiles;

Lactobacillus delbrueckii ssp. bulgaricus;

Lactobacillus acidopgilus;

Bifidobacterium lactis.
Розроблена технологія термостатного йогурту 3 мчж $1,5 \%$ із кріопорошком "Морська капуста", яка передбачає як прототип вітчизняний термостатний йогурт “Салатний” (ДСТУ 4343:2004).

За результатами проведених експериментів нами було відібрано по 3-4 найбільш вдалі зразки йогуртів iз додаванням пропонованої кріодобавки у різних співвідношеннях. Дослідні рецептури перераховувались на 1000 кг готового продукту (без урахування виробничих втрат).

Проведення оцінки якісних показників досліджуваних кисломолочних напоїв відбулося згідно із загальноприйнятими методиками. Органолептичні показники (зовнішній вигляд, структура і консистенція, смак і запах, колір) йогурту оцінювали згідно з ДСТУ 
4343:2004 “Йогурти. Загальні технічні умови” та "Інструкцією про порядок проведення органолептичної оцінки м'ясо-молочних продуктів" за допомогою органів відчуття.

При виконанні досліджень титровану кислотність зразків визначали титрометричним методом за ГОСТ 3624-92, активну кислотність - потенціометричним методом за ГОСТ 25754-85, температуру - за ГОСТ 25754-85.

\section{Таблиця 1}

Рекомендована оптимальна рецептура термостатний йогурт (мчж 1,5 \%) із кріопорошком “Морська капуста"

\begin{tabular}{lcc}
\hline \multicolumn{1}{c}{ Складники рецептур } & \multicolumn{2}{c}{ Рецептури йогурту } \\
\cline { 2 - 3 } & традиційна & дослідна \\
\hline Молоко незбиране (мчж 3,2 \%) & 487,00 & 461,46 \\
Молоко знежирене (0,05 \%) & 325,90 & 48.44 \\
Сухе молоко знежирене (100 \% розчинності) & 46,1 & 46,1 \\
Закваска прямого внесення “іn vivo" & 0,1 & 0,1 \\
Кріопорошок “Морська капуста” & - & 10 \\
Плодово-ягідний сироп & 141,00 & - \\
Всього & 1000 & 1000 \\
\hline
\end{tabular}

В характеристиці молочних продуктів, в тому числі й при виготовленні нових чи їх видозмін, вкрай важливим є забезпечення нормативної їх органолептики. Як відомо, органолептика продуктів визначається технологічним процесом, видом і якістю застосовуваних заквасок, кольором молока, харчових внесених добавок, що використовуються при їх виготовленні, виду та якості фасувального матеріалу, умов зберігання та асортименту.

Останніми роками велике зацікавлення викликають кріопорошки, а їхнє оптимальне поєднання із “молочними основами" різних молочних продуктів викликає потребу в розробці оптимальних промисло-

\section{Результати та їх обговорення}

За результатами роботи дегустаційної комісії як найкращу визнано рецептуру, до складу якої (в перерахунку на 1000 кг готового продукту) входять молоко незбиране (мчж 3,2 \%) - 461,46 кг, знежирене молоко (мчж 0,05 \%) - 482,44 кг, сухе молоко знежирене (100\% розчинності) - 46,1 кг, закваска прямого внесення "in vivo" - 0,1кг, та 10 кг кріопорошок "Морська капуста" (табл. 1).

\section{Таблиця 2}

Органолептичні властивості дослідних зразків термостатного йогурту (мчж 1,5 \%) із використанням як вітамінного наповнювача кріопорошку “Морська капуста"

\begin{tabular}{ll}
\hline $\begin{array}{c}\text { Зовнішній вид і } \\
\text { консистенція }\end{array}$ & Згусток сформований. На дні тари наявні численні включення світло - та темно-зеленого кольору \\
\hline Смак і запах & Свіжий, кисломолочний, чітко виражений присмак кріопорошку “Морська капуст”. Після перемі- \\
Колір & $\begin{array}{l}\text { шування (порушення згустку) запах і смак більш виражені із чітким присмаком кріопорошку } \\
\text { Кремовий / після перемішування із численними вкрапленнями світло - та темно-зеленого кольору }\end{array}$ \\
\hline
\end{tabular}

Ще однією важливою групою показників для характеристики молочних продуктів є фізико-хімічні їх характеристики.

Як відомо, згідно з нормативними вимогами всі йогурти, що випускаються молокопереробною галуззю в Україні, повинні відповідати певним константам (титрована кислотність; вміст вологи та жиру, енергетична цінність та інші).

Фізико-хімічні показники дослідних зразків солодких йогуртів із використанням як наповнювача нового покоління кріопорошку "Морська капуста" та тра- вих рецептур та комплексне дослідження дослідних зразків на їх органолептичну, фізико-хімічну відповідність щодо існуючих нормативних вимог, наявність у них вітамінів та інших біологічно активних добавок.

У таблиці 2. наведено дані органолептичних властивостей дослідних зразків термостатного йогурту (мчж 1,5 \%) із використанням якості вітамінного наповнювача кріопорошку “Морська капуста". Як видно iз отриманих органолептичних характеристик, дослідні зразки термостатного йогурту (мчж 1,5 \%) із використанням як вітамінного наповнювача кріопорошку "Морська капуста" загалом відповідали нормативним органолептичним характеристикам. диційних (молочного i фруктового) наведені у таблиці 3.

Аналіз цифрового матеріалу показує, що фізикохімічні характеристики базового йогурту (мчж 1,5\%), iз використанням традиційних солодких наповнювачів та кріопорошку “Морська капуста” суттєво відрізнялись.

Дослідні зразки пропонованого нами йогурту мали вміст жиру $1,5 \%$; тимчасом як вміст сухих речовин склав 17,8 \%; кількість солі складала $3,2 \%$. 
Таблиця 3

Фізико-хімічні показники термостатного йогурту із кріопорошком "Морська капуста"

\begin{tabular}{|c|c|c|c|c|c|c|}
\hline \multirow[b]{2}{*}{$\begin{array}{l}\text { № } \\
\Pi / \Pi\end{array}$} & \multirow[b]{2}{*}{ Види йогурту } & \multicolumn{3}{|c|}{ Масова частка основних складових } & \multicolumn{2}{|l|}{ Кислотність , ${ }^{\circ} \mathrm{T}$} \\
\hline & & \% жиру & \% цукру/солі & $\mathrm{CP}$ & $\begin{array}{c}\text { На початку } \\
\text { сквашування }\end{array}$ & $\begin{array}{c}\text { В кінці } \\
\text { сквашування }\end{array}$ \\
\hline 1. & Молочний & $0,2-2,5$ & - & 16 & $75-85$ & $80-110$ \\
\hline 2. & Фруктовий & $3,5-4,0$ & 5 \% цукру & 21,00 & $75-85$ & $80-110$ \\
\hline 3. & $\begin{array}{l}\text { із кріопорошком } \\
\text { "Морська капуста" }\end{array}$ & 1,5 & $3,2 \%$ солі & 17,8 & 82 & 105 \\
\hline
\end{tabular}

Водночас титрована кислотність дослідних зразків солодких зразків йогурту (мчж $1,5 \%$ ) із використанням як наповнювача кріопорошку "Морська капуста" повністю відповідала нормативним вимогам як на початку сквашування, так і в кінці виготовлення. Виявлені нами фізико-хімічні характеристики у дослідних зразках термостатного йогурту ми пов'язуємо із вмістом використаного кріопорошку “Морська капуста". Важливою вимогою до якості функціональних продуктів є їхня відповідність потребам збалансованого живлення за пластичними і енергетичними речо- винами, таким як білки, жири, вуглеводи, мінеральні елементи, вітаміни.

Отримані експериментальні дані наступної таблиці 4 засвідчують, що збагачення термостатного йогурту кріопорошком "Морська капуста" призводить до суттєвого зростання вмісту всіх нормативно передбачених вітамінів. Особливо варто наголосити на прирості вітаміну С як одного із важливих чинників підтримання імунного статусу організму потенційного споживача.

\section{Таблиця 4}

Вітамінний та мінеральний склад термостатного йогурту із кріопорошком “Морська капуста"

\begin{tabular}{|c|c|c|c|c|c|c|c|c|}
\hline \multirow{2}{*}{$\begin{array}{l}№ \\
\Pi / \Pi \\
\end{array}$} & \multirow{2}{*}{ Продукт } & \multicolumn{4}{|c|}{ Вміст вітамінів (мг в 100 г продукту) } & \multicolumn{3}{|c|}{ Мінеральний склад } \\
\hline & & $\mathrm{B}_{1}$ & $\mathrm{~B}_{2}$ & $\mathrm{C}$ & $\mathrm{A}$ & $\mathrm{Ca}$ & $\mathrm{K}$ & $\mathrm{Mg}$ \\
\hline 1. & Нормативні вимоги & 0,04 & 0,18 & 0,9 & 0,01 & 124 & 152 & 15 \\
\hline 2. & $\begin{array}{l}\text { Йогурт низької } \\
\text { цукру (мчж } 1 \% \text { ) }\end{array}$ & 0,04 & 0,19 & 0,92 & 0,01 & 125 & 153 & 16 \\
\hline 3. & $\begin{array}{l}\text { Йогурт із кріопорошком } \\
\text { "Морська капуста" }\end{array}$ & 0,07 & 0,23 & 1,5 & 0,03 & 128 & 162 & 18 \\
\hline
\end{tabular}

Водночас при створенні таких продуктів потрібно обов'язково оцінювати як харчову, та і біологічну повноцінність. Це, зокрема, стосується їхнього білкового складу. Для цього нами досліджено амінокислотний склад виготовленого йогурту 3 кріопорошком “Морська капуста".

Як видно 3 даних таблиці 5, додавання до йогурту кріопорошку 3 морської капусти в кількості 10 г на 1 літр готового продукту збільшило в ньому порівняно 3 традиційним зразком вміст незамінних амінокислот на 2,53 \%, замінних - на 4,19\%, а їхню загальну кількість - на 3,5\%.

В комбінованому зразку йогурту відбувся перерозподіл концентрацій більшості амінокислот. У складі незамінних амінокислот порівняно 3 рештою кислот значно більше зріс рівень триптофану (9,33 \%). Майже в 3 рази меншим було зростання треоніну (2,96\%), ізолейцину $(2,96 \%)$, дещо меншим - валіну (2,46 \%), метіоніну $(2,44 \%)$, лізину $(2,31 \%)$, найменшим - лейцину $(1,87 \%)$ і фенілаланіну $(2,01 \%)$.

Більш помітніші зміни виявлено серед замінних амінокислот. Помітно більшим було зростання вмісту цистину $(17,18 \%)$, гліцину $(15,77 \%)$, аланіну $(11,90 \%)$, значно меншим - вмісту аспарагінової кислоти $(4,76 \%)$, аргініну $(4,83 \%)$, серину $(4,49 \%)$, глютамінової кислоти $(3,65 \%)$. Незначно збільшувався вміст проліну $(1,20 \%)$, тирозину $(0,64 \%)$, гістидину $(1,40 \%)$.
Встановлене нами збільшення вмісту окремих амінокислот при додаванні до йогурту кріопорошку 3 морської капусти пояснюється більшим у 3 рази вмістом білка в рослинному препараті.

Значно більше зростання вмісту замінних амінокислот, ніж незамінних, було обумовлене тим, що в рослинних білках кількість замінних амінокислот помітно більша, ніж у тваринних білках. Зокрема, в традиційному йогурті 1,5 \% жирності відсоток суми замінних амінокислот складав 58,24 \%, а в кріопорошку з морської капусти - 66,45 \%.

Встановлене нами збільшення в комбінованому зразку йогурту цілого ряду незамінних і замінних амінокислот може мати позитивний вплив на процеси життєдіяльності організму людини як самих амінокислот, необхідних для синтезу білків тіла, так і шляхом утворення із них біологічно активних білків та сполук.

Хоча в йогурті з додаванням кріопорошку з морської капусти відбувалося зростання концентрації цілої низки замінних і незамінних амінокислот, в ньому порівняно 3 традиційним зразком не спостерігалось зміни співвідношення між сумами цих амінокислот, яке складало в цих зразках відповідно 41,76 і 41,37 \% та 58,63 і 58,24\%. Це дозволяє стверджувати, що засвоєння та використання амінокислот комбінованого зразка йогурту було аналогічним традиційному зразку. Як відомо, одночасне споживання тваринних і рослинних білків підвищує перетравність білка останніх і тим самим передовсім їхню харчову цінність. 


\section{Таблищя 5}

Вміст амінокислот в йогурті (мчж 1,5 \%) із кріопорошком “Морська капуста"

\begin{tabular}{|c|c|c|c|c|}
\hline \multirow{3}{*}{ Амінокислоти } & \multicolumn{4}{|c|}{ Зразки йогурту } \\
\hline & \multicolumn{2}{|c|}{ традиційний } & \multicolumn{2}{|c|}{ з кріопорошком } \\
\hline & г/л йогурту & $\begin{array}{c}\text { \% від вмісту аміно- } \\
\text { кислот }\end{array}$ & г/л йогурту & $\begin{array}{c}\% \text { від вмісту аміноки- } \\
\text { слот }\end{array}$ \\
\hline \multicolumn{5}{|l|}{ Незамінні амінокислоти } \\
\hline Треонін & 1,384 & 4,32 & 1,425 & 4,30 \\
\hline Валін & 2,070 & 6,46 & 2,121 & 6,40 \\
\hline Метіонін & 0,737 & 2,30 & 0,755 & 2,28 \\
\hline Ізолейцин & 1,923 & 6,00 & 1,980 & 5,97 \\
\hline Лейцин & 2,884 & 9,00 & 2,936 & 8,85 \\
\hline Фенілаланін & 1,442 & 4,50 & 1,471 & 4,43 \\
\hline Лізин & 2,480 & 7,74 & 2,527 & 7,62 \\
\hline Триптофан & 0,461 & 1,44 & 0,504 & 1,52 \\
\hline Разом & 13,381 & 41,76 & 13,719 & 41,37 \\
\hline \multicolumn{5}{|l|}{ Замінні амінокислоти } \\
\hline Аспарагінова кислота & 2,205 & 6,88 & 2,308 & 6,96 \\
\hline Серин & 1,782 & 5,56 & 1,862 & 5,61 \\
\hline Глютамінова кислота & 5,749 & 17,94 & 5,959 & 17,07 \\
\hline Пролін & 3,320 & 10,96 & 3,360 & 10,13 \\
\hline Гліцин & 0,596 & 1,92 & 0,690 & 2,08 \\
\hline Аланін & 1,025 & 3,20 & 1,147 & 3,46 \\
\hline Цистин & 0,320 & 1,00 & 0,375 & 1,13 \\
\hline Тирозин & 1,551 & 4,84 & 1,561 & 4,71 \\
\hline Гістамін & 1,000 & 3,12 & 1,014 & 3,06 \\
\hline Аргінін & 1,115 & 3,42 & 1,169 & 3,52 \\
\hline Разом & 18,663 & 58,24 & 19,445 & 58,63 \\
\hline Всього & 32,044 & 100,0 & 33,164 & 100,0 \\
\hline
\end{tabular}

Біологічна цінність харчового білка у продукті може оцінюватися шляхом порівняння його амінокислотного складу з амінокислотним складом стандартного “ідеального” білка. Під ідеальним білком розуміють гіпотетичний білок високої харчової цінності, що повністю задовольняє потребу організму людини в незамінних амінокислотах.

Найбільшим прийнятним способом оцінки біологічної цінності білка харових продуктів є метод визначення так званого амінокислотного скору. Метод грунтується на зіставленні амінокислотного складу білка конкретного продукту з амінокислотним складом гіпотетичного “ідеального” білка, який повністю збалансований за незамінними амінокислотами.

Як видно із таблиці 6, в йогурті 3 додаванням кріопорошку 3 морської капусти величини вмісту незамінних амінокислот були близькими до показників традиційного продукту за винятком суми сірковмісних амінокислот і триптофану, вміст яких дещо зростав, та суми ароматичних амінокислот і лізину, рівень яких незначно знижувався.

\section{Таблиця 6}

Вміст амінокислот в 100г білка йогурту з кріопорошком "Морська капуста"

\begin{tabular}{lccc}
\hline \multirow{2}{*}{ Амінокислоти } & \multirow{2}{*}{ Еталонний білок } & \multicolumn{2}{c}{ Зразки йогурту } \\
\cline { 3 - 4 } Ізолейцин & 4,0 & традиційний & 3 кріопорошком \\
Лейцин & 7,0 & 6,00 & 5,97 \\
Сума ароматичних (фенілаланін + тирозин) & 6,0 & 9,00 & 9,85 \\
Сума сірковмісних (метіонін + цистин) & 3,5 & 9,34 & 3,41 \\
Треонін & 4,0 & 3,30 & 4,30 \\
Валін & 5,0 & 4,32 & 6,40 \\
Лізин & 5,5 & 6,46 & 7,62 \\
Триптофан & 1,0 & 7,74 & 1,52 \\
\hline
\end{tabular}

Порівняно з еталонним білком, за винятком суми сірковмісних амінокислот в обох зразках йогурту, був вищий вміст амінокислот, для яких враховуються амінокислотні скори. Найбільше був підвищений рівень суми ароматичних амінокислот, валіну, лізину та триптофану. Показник суми сірковмісних амінокислот був менший від “еталонного” білка, особливо в традиційному зразку йогурту. Меншими були різниці щодо ізолейцину, лейцину, треоніну.

Обрахунок величин амінокислотних скорів не виявив помічених різниць більшості амінокислот (табл. 7). Витяток складає триптофан, скор якого зростав. Важливо зазначити, що скор суми сірковмісних амінокислот (метіонін + цистин) зростав до величини, 
яка вказує на те, що в комбінованому зразку йогурту сума цих амінокислот не є лімітуючою. Це відбувалося за рахунок збільшення меншою мірою метіоніну $(2,44 \%)$ та в більшою мірою цистину $(17,18 \%)$. Середні скори обох йогуртів були високими і практично однаковими, що свідчить про високу біологічну цінність комбінованого зразка.
Узагальнюючи отримані результати, можна зробити висновок, що використання при виготовленні йогурту 1,5 \% жирності в кількості 10 г на літр продукту кріопорошку з морської капусти обумовило зростання харчової і біологічної цінності комбінованого продукту за білковою складовою.

\section{Таблиця 7}

Амінокислотні скори йогурту з кріопорошком “Морська капуста”

\begin{tabular}{lcc}
\hline \multirow{2}{*}{\multicolumn{1}{c}{ Амінокислоти }} & \multicolumn{2}{c}{ Зразки йогурту } \\
\cline { 2 - 3 } & традиційний & 3 кріопорошком \\
\hline Ізолейцин & 150,0 & 149,25 \\
Лейцин & 128,57 & 126,43 \\
Сума ароматичних (фенілаланін + тирозин) & 155,67 & 152,33 \\
Сума сірковмісних (метіонін + цистин) & 94,28 & 97,43 \\
Треонін & 108,0 & 107,5 \\
Валін & 129,2 & 128,0 \\
Лізин & 140,73 & 138,54 \\
Триптофан & 144,0 & 152,0 \\
Середнє & 131,31 & 131,43 \\
\hline
\end{tabular}

В йогурті 3 кріопорошком зростав як загальний вміст амінокислот (3,50 \%), так і сума незамінних $(2,53 \%)$ і замінних амінокислот $(4,19 \%)$. Відбувалось зростання концентрації всіх амінокислот. Якщо це зростання незамінних амінокислот було майже однакове для всіх кислот за винятком триптофану, то серед замінних амінокислот спостерігались значні розбіжності у величинах збільшення їх вмісту. Найбільш помітним було підвищення рівня гліцину $(15,77 \%)$, цистину $(17,18 \%)$, аланіну (11,9\%).

В 2-3 рази менше зростав вміст аспарагінової кислоти $(4,76 \%)$, серину $(4,49 \%)$, аргініну $(4,58 \%)$, глютамінової кислоти $(3,65 \%)$. Зовсім незначно змінювався вміст тирозину $(0,64 \%)$, проліну $(1,20 \%)$, гістидину $(1,40 \%)$.

Зростання скору суми сірковмісних амінокислот (метіонін + цистин) і триптофану та відсутність лімітуючих амінокислот в комбінованому зразку йогурту свідчить про підвищення біологічної цінності цього продукту.

Важливо, що співвідношення суми незамінних i замінних амінокислот було однаковим в обох зразках йогурту, що свідчить про близькі параметри величин засвоєння та використання білка в організмі людини.

Вкрай важливим показником безпеки даних продуктів $є$ їхня мікробіологічна безпека. Проведені дослідження засвідчують, що при зберіганні у всіх дослідних зразках йогурту встановлено нормативні величини мікробного пейзажу, вміст БГКП був негативним, а величини титрованої кислотності також суттєво не змінювались. Варто зазначити, що приріст титрованої кислотності з $85-120$ та $82-130^{\circ} \mathrm{T}$, виявлений у традиційних та дослідних зразках йогурту із використанням кріопорошку “Морська капуста", був у межах нормативних вимог (особливо у 72-годинний проміжок із моменту їх виготовлення ).

За результатами комплексу проведених досліджень рекомендовано пропоновані зразки термостатних йогуртів із використанням кріопорошку “Морська капуста" з метою розширення асортименту йогурту пониженої жирності як в умовах базового підприємства, так і з метою розширення базового асортименту та продукції лікувально-профілактичного напрямку.

\section{Висновки}

1. Розроблені та запропоновані для промислового виробництва рецептури термостатних йогуртів (мчж 1,5\%) із кріопорошком вітчизняного виробництва "Морська капуста".

2. Запропонована технологічна схема виробництва термостатних йогуртів (мчж 1,5\%) із кріопорошком вітчизняного виробництва "Морська капуста"

3. Вивчено основні органолептичні та технологічні характеристики термостатних йогуртів (мчж $1,5 \%$ ) із кріопорошком вітчизняного виробництва "Морська капуста".

4. Дослідні зразки термостатних йогуртів (мчж $1,5 \%$ ) із кріопорошком вітчизняного виробництва "Морська капуста" мали підвищені показники вмісту всіх нормативно передбачених вітамінів.

5. Пропоновані види термостатних йогуртів (мчж 1,5 \%) із кріопорошком "Морська капуста" характеризуються зростанням скору суми сірковмісних амінокислот (метіонін + цистин) і триптофану, а відсутність лімітуючих амінокислот в комбінованому зразку йогурту свідчить про підвищення біологічної цінності продукту.

6. Дослідні зразки термостатних йогуртів (мчж $1,5 \%)$ із кріопорошком вітчизняного виробництва “Морська капуста" зберігали технологічні характеристики та нормативні показники безпеки протягом нормативного часу зберігання.

\section{References}

Berhilevych, O. M., Kasianchuk, V. V., \& Salata, V. Z. (2010). Mikrobiolohiia moloka i molochnykh produktiv z osnovamy veterynarno-sanitarnoi ekspertyzy: Navch. posibnyk. Sumy (in Ukrainian). 
Bilyk, O., Slyvka, N., Gutyj, B., Dronyk, H., \& Sukhorska, O. (2017). Study of the different ways of proteins extraction from sheep and cow whey for "Urda" cheese production. EUREKA: Life Sciences, 3, 3-8. doi: 10.21303/2504-5695.2017.00333.

DSTU 2212:2003 (2004). Vyrobnytstvo moloka ta kyslomolochnykh produktiv. K.: Natsionalnyi standart Ukrainy (in Ukrainian).

Gutyj, B., Hachak, Y., Vavrysevych, J., \& Nagovska, V. (2017). The influence of cryopowder "Garbuz" on the technology of curds of different fat content. EasternEuropean Journal of Enterprise Technologies, 2(10(86)), 20-24. doi: 10.15587/1729-4061.2017.98194.

Hachak, Yu. R., Nahovska, V. O., Ryvak, D., \& Rabshtyna, Yu. (2015). Syropy spetspryznachennia v tekhnolohii solodkykh kyslomolochnykh napoiv. Naukovyi visnyk LNUVM ta BT imeni S.Z.Hzhytskoho, 17(4(64), 41-46. URL: http://nbuv.gov.ua/UJRN/nvlnu 201517410 (in Ukrainian).

Hachak, Yu., Gutyj, B., Bilyk, O., Nagovska, V., \& Mykhaylytska, O. (2018). Investigation of the "Amaranth" cryoadditive on organoleptic and microbiological parameter of processed cheeses. Eureka: Life Sciences, 1(13), 18-24. doi: 10.21303/2504-5695.2018.00555.

Hachak, Yu., Gutyj, B., Bilyk, O., Nagovska, V., \& Mykhaylytska, O. (2018). Effect of the cryopowder "Amaranth" on the technology of meolten cheese. Eastern-European Journal of Enterprise Technologies. 2018, 1(11(91), 10-15. doi: 10.15587/1729-4061.2018.120879.

Hoshko, K., \& Tsisaryk, O. I. (2016). Rozroblennia tekhnolohii yohurtu iz bifidobakteriiamy ta naturalnymy i syntetychnymy komponentamy. Materialy Mizhnarodnoi konferentsiia "Dni studentskoi nauky" u Lvivskomu natsionalnomu universyteti veterynarnoi medytsyny ta biotekhnolohii imeni S. Z. Hzhytskoho. Lviv, 12-13 travnia 2016 r., 3, 95-96 (in Ukrainian).

Pinheiro, M. V. S., Oliveira, M. N., Penna, A. L. B., \& Tamime, A. Y. (2005). The effect of different sweeteners in low-calorie yogurts - A review. International
Journal of Dairy Technology, 58(4), 193-199. doi: 10.1111/j.1471-0307.2005.00228.x.

Ramazashvili, H. R., \& Kruchen, O. A. (2016). Perspektyvy vyrobnytstva kombinovanykh yohurtovykh napoiv iz zastosuvanniam spelty. Materialy Mizhnarodnoi konferentsiia "Dni studentskoi nauky" u Lvivskomu natsionalnomu universyteti veterynarnoi medytsyny ta biotekhnolohii imeni S. Z. Hzhytskoho. Lviv, 12-13 travnia 2016 r., 3, 127-128 (in Ukrainian).

Reis, R. C., Minim, V. P. R., Bolini, H., Dias, B. R. P., Minim, L. A., \& Ceresino, E. B. (2011). Sweetness equivalence of different sweeteners in Strawberryflavored yogurt. Journal of Food Quality, 34, 163170. doi: 10.1111/j.1745-4557.2011.00378.x.

Smith, G. P. S., Holroyd, S. E., Reid, D. C. W., \& Gordon, K. C. (2016). Raman imaging processed cheese and its components. Journal of Raman Spectroscopy, 48(3), 374-383. doi: 10.1002/jrs.5054.

Steshenko, I. Iu., \& Haiho, I. Iu. (2016). Rozrobka fitokompozytsii dlia vyrobnytstva funktsionalnykh kyslomolochnykh syriv. Zh. Problemy stareniia i dolholetiia, 25(2), 273-279 (in Ukrainian).

TU U 15.5-19492247-002-2002 (2002). Yohurty elitni. Tekhnichni umovy Kyiv (in Ukrainian).

TUU 15.5-19492247-004-2003 (2003). Napoi kyslomolochni. Ukr. TsSM (in Ukrainian).

Vlasenko, I. H. (2013). Rozshyrennia asortymentu produktiv LPN zavdiaky pry vyhotovlenni produktiv, v yakykh laktokoky zi vysokoiu proteoloitychnoiu vlastyvistiu. Naukovyi visnyk LNUVM imeni S.Z. Hzhytskoho, 15(1(55), 53-57 (in Ukrainian).

Yatsenko, I. V., Bohatko, N. M., Bukalova, N. V., Fotina, T. I., Biben, I. A., Berhilevych, O. M., Hachak, Yu. R., Tkachuk, S. A., Kamianskyi, V. V., Bondarevskyi, M. M., Zazharska, N. M., Tsyvirko, I. L., \& Kasianenko, O. M. (2016). Hihiiena moloka i molochnykh produktiv. Chastyna 2. Hihiiena molochnykh produktiv: Pidruchnyk. Kharkiv: "Disa plius" (in Ukrainian). 